\title{
A new Middle Pleistocene interglacial sequence from Måløv, Sjælland, Denmark
}

\author{
Ole Bennike, Esben Lindgård, Henrik Jønsson Granat, Richard C. Preece and Finn Viehberg
}

Interglacial deposits in Denmark have traditionally been referred to the Cromerian complex (Hareskovian), Holsteinian or Eemian stages. However, based on studies of sediment cores from the deep sea many more than three Quaternary interglacials have been documented, and in other parts of north-western Europe it is becoming increasingly clear that the on-shore Quaternary sequences are much more complex than previously believed. Interglacial deposits are characterised by plant and animal remains indicating longer periods with climatic conditions similar to or warmer than today, whereas interstadial deposits were formed during shorter time spans and usually contain remains of relatively coldadapted, arctic or sub-arctic species. Interglacial and interstadial deposits can be dated more or less precisely, and thus provide information about the relative age of glacial deposits.

In 2010 the Geological Survey of Denmark and Greenland (GEUS) described samples from a $75 \mathrm{~m}$ deep borehole at $55^{\circ} 45.37^{\prime} \mathrm{N}, 12^{\circ} 19.63^{\prime} \mathrm{E}$ (elevation $20.7 \mathrm{~m}$ a.s.l.), at the address Bakketoften 50 in Måløv on north-eastern Sjælland (Fig. 1). Coring was conducted for Ballerup municipality (kommune) using the reverse circulation technique ('omvendt skylning med lufthævning') by the well-drilling company Thomas Brøker, and samples were collected every 2 $\mathrm{m}$ and sent to GEUS. A few shells of freshwater gastropods were noted, and since pre-Holocene shell-bearing deposits are rare on Sjælland, we decided to analyse the macrofossil content. We initially assumed that the sediments were deposited in a lake during a Weichselian interstadial, because an interstadial deposit was reported from Måløv by Frederiksen \& Rosbirk (1999). However, we question this dating since Frederiksen and Rosbirk did not provide any data that could confirm an interstadial age or a lacustrine environment. This article gives details of macrofossil analyses of five samples from the borehole, which allow for more definite conclusions about the depositional environment of the site and its possible age.

\section{Lithostratigraphy}

The drilling penetrated $52 \mathrm{~m}$ of Quaternary sediments, $16 \mathrm{~m}$ of Danian limestone and $7 \mathrm{~m}$ of Cretaceous chalk (Fig. 2). It stopped at a depth of $75 \mathrm{~m}$ below the ground surface. The
Quaternary sediments are dominated by glacial till and meltwater deposits. However, a unit of clay with a few shells of freshwater gastropods was found between 34 and $44 \mathrm{~m}$. The clay unit is underlain and overlain by clayey till.

\section{Material and methods}

Five sediment samples were available for analysis of macrofossils, each weighing around $1 \mathrm{~kg}$. The samples were soaked in a $\mathrm{NaOH}$ solution at room temperature for two weeks and wet sieved on $0.4,0.2$ and $0.1 \mathrm{~mm}$ sieves. The residue left on the sieves was analysed using a dissecting microscope. The plant and animal remains studied are much larger than for example pollen grains or diatom frustules, and we call them macrofossils, even though for example ostracods are traditionally considered microfossils by palaeontologists.

\section{Palaeoecology}

The results of the macrofossil analyses are presented in Table 1. One of the samples did not contain any macrofossils, one contained only a few moss remains, one contained

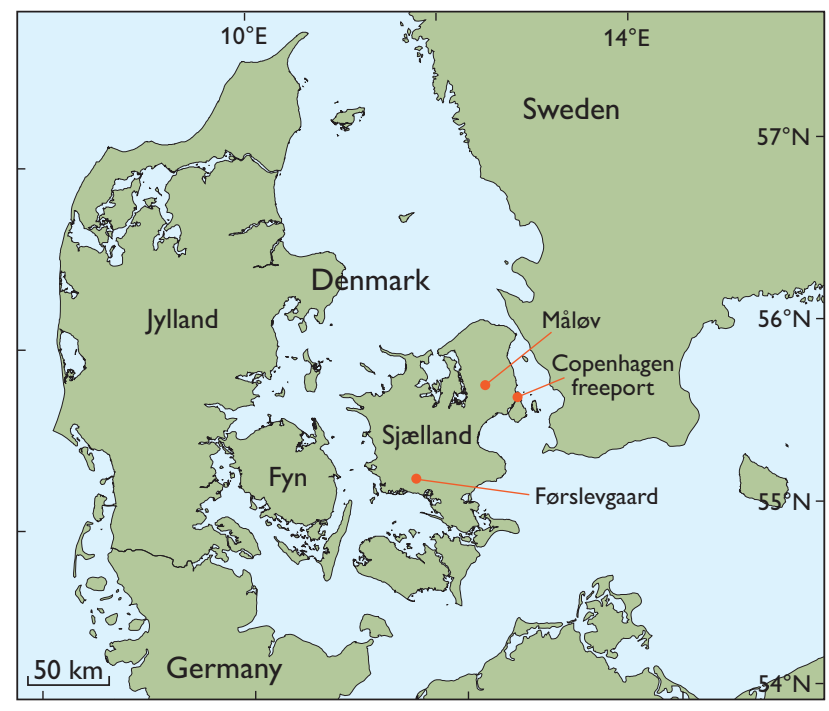

Fig. 1. Map of Denmark showing the location of Måløv and other localities on Sjælland with non-marine interglacial deposits discussed in the text. 


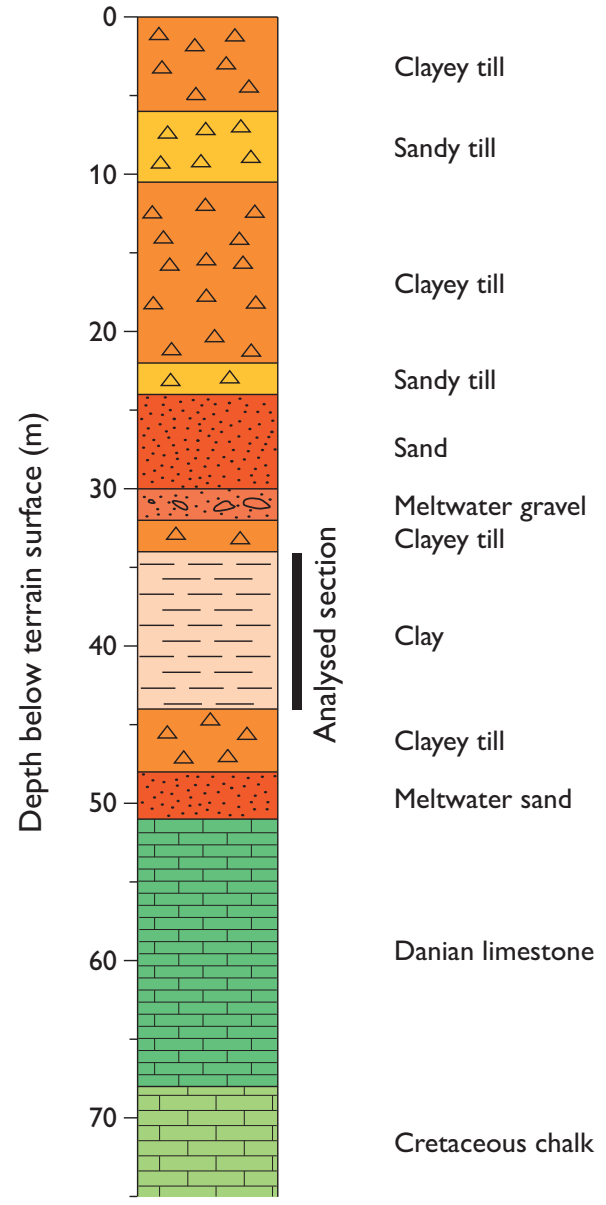

Fig. 2. Lithological log of core DGU 200.5351 from Måløv.

frequent moss remains and a few other macrofossils. The two most shallow samples were somewhat richer in macrofossils, but their concentration and diversity are low.

The macrofossils are dominated by freshwater organisms, but at least one brackish-water species, the ostracod Cyprideis torosa, is also present. It occurred with articulated carapaces, suggesting that reworking is unlikely. The carapaces and shells of C. torosa are noded (forma torosa), a feature indicating a salinity <7\%o (Meisch 2000; Frenzel et al. 2010). Shells of freshwater gastropods are also present. Some are fragmented, but this damage may have occurred during coring. The presence of both brackish-water and freshwater organisms implies low salinity conditions that would allow such a co-occurrence. A similar situation is found in many places today, for example at river mouths, in estuaries and in the Gulf of Bothnia. The lack of head capsules of Chironomidae, as well as carapaces and head shields of Cladocera, may also imply weakly brackish waters. Interglacial lake deposits usually contain hundreds of head capsules of non-biting midge larvae (chironomids) per millilitre sediment, and
Table 1. Macrofossils in five samples from interglacial deposits near Måløv

\begin{tabular}{|c|c|c|c|c|c|}
\hline $\begin{array}{l}\text { Sample no. } \\
\text { Depth (m) }\end{array}$ & $\begin{array}{l}38775 \\
34-36\end{array}$ & $\begin{array}{l}38776 \\
36-38\end{array}$ & $\begin{array}{l}38777 \\
38-40\end{array}$ & $\begin{array}{l}38778 \\
40-42\end{array}$ & $\begin{array}{l}38779 \\
42-44\end{array}$ \\
\hline \multicolumn{6}{|l|}{ Mosses } \\
\hline Bryum sp. & - & - & - & $r$ & c \\
\hline Polytrichum s.l. sp. & 1 & - & - & - & - \\
\hline Sphagnum sp. & 2 & 3 & - & - & - \\
\hline \multicolumn{6}{|l|}{ Vascular plants } \\
\hline Nymphaeaceae indet. & 1 & - & - & - & - \\
\hline Potentilla sp. & - & 1 & - & - & - \\
\hline Rumex maritimus & - & 4 & - & - & - \\
\hline Stratiotes aloides & 2 & - & - & - & 1 \\
\hline Typha sp. & 2 & - & - & - & - \\
\hline Juncus sp. & 1 & - & - & - & - \\
\hline \multicolumn{6}{|l|}{ Ostracods } \\
\hline Cyprideis torosa & 4 & - & - & - & - \\
\hline Scottia tumida & $r$ & 1 & - & - & - \\
\hline Darwinula stevensonia & 1 & - & - & - & - \\
\hline \multicolumn{6}{|l|}{ Molluscs } \\
\hline Borysthenia naticina & 9 & 3 & - & - & - \\
\hline Sphaerium cf. solidum & 1 & - & - & - & - \\
\hline Sphaerium cf. corneum & $r$ & - & - & - & - \\
\hline Sphaerium sp. & - & $r$ & - & - & - \\
\hline Pisidium supinum & 2 & - & - & - & - \\
\hline Pisidium moitessierianum & 2 & - & - & - & - \\
\hline Bivalvia indet. & - & $r$ & - & - & - \\
\hline \multicolumn{6}{|l|}{ Bryozoans } \\
\hline Plumatella repens & 2 & 1 & - & - & 3 \\
\hline Fredericella indica & - & - & - & - & 2 \\
\hline Cristatella mucedo & - & 1 & - & - & - \\
\hline
\end{tabular}

r: rare, c: common.

thousands of cladoceran remains per millilitre. Although it is risky to use negative evidence, we suggest that the absence of chironomid and cladoceran remains is due to brackish-water conditions. On the other hand, the lack of these remains could perhaps also be attributed to poor preservation, but the other macrofossils are well preserved, and this possibility is considered unlikely. No rivers are found on Sjælland today, and it may be speculated if the deposit formed near the outlet from a former freshwater or brackish water Baltic Sea, somewhat similar to the palaeogeographical situation in the early Holocene.

The assemblage of freshwater taxa comprises at least 12 species. Macrolimnophytes are represented by a species of Nymphaeaceae (water lily, 1 leaf hair) and Stratiotes aloides (water soldier, 3 leaf-margin spines). These water plants grow in shallow water, in lakes or in streams with slowly flowing water. Both are typical of mesotrophic to eutrophic waters. Freshwater ostracods are represented by Darwinula stevensoni and Scottia tumida (Fig. 3) and freshwater molluscs by the gastropod Borysthenia naticina (Fig. 4) and the bivalves 


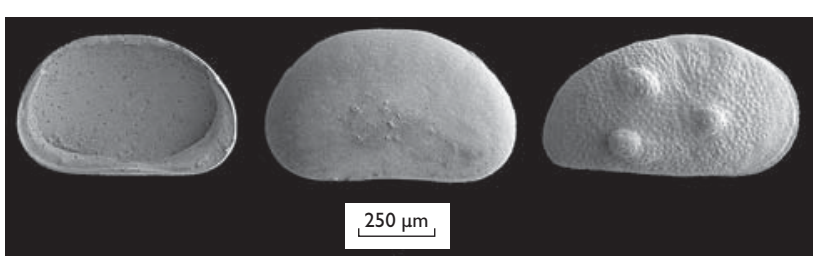

Fig. 3. Scanning electron microscope images of ostracode shells from Måløv. A: Scottia tumida (internal view). B: Scottia tumida (external view). C: Cyprideis torosa (external view, juvenile).

Sphaerium cf. solidum, Sphaerium cf. corneum, Pisidium supinum and Pisidium moitessierianum. These are species characteristic of fluvial environments. Statoblasts of three species of bryozoans were found: Cristatella mucedo, Plumatella sp. and Fredericella indica. The bryozoans may have lived on water plants.

Fredericella indica is rarely recorded as a fossil, probably because its statoblasts are indistinctive. However, it has been found in Middle Weichselian interstadial deposits in Sweden, in late-glacial deposits in Norway and in Holocene deposits in Norway, Denmark and Greenland.

We cannot say if the remains of freshwater plants come from plants that grew in the depositional basin or if they were washed into the basin from freshwater environments in the catchment area. It is also possible that some of the remains of invertebrates, notably the statoblasts, may have been transported from lakes or streams into the basin. Most of the freshwater species can occur in many different freshwater biotopes, but overall they are characteristic of a low-energy fluvial environment. The presence of $C$. torosa suggests some influence by marine water.

The fine texture of the sediment (clay) implies deposition in a low-energy environment, such as a river with weak bottom currents. The presence of clay rather than gyttja indicates deposition in a river rather than in a lake.

Non-aquatic moss taxa are dominated by the mosses Bryum sp. and Sphagnum sp. but a leaf of the moss Polytrichum s.l. sp. was also recovered. Vascular land plants are represented by one achene of Potentilla sp., one seed of Juncus sp., two fruits of Typha sp. and four fruits of Rumex maritimus. The latter may indicate salt-water influence, supporting the evidence from C. torosa, although it is also found at inland sites today. Several of these species probably grew in mires along the shore of the former water body where the clay was deposited. In particular, Sphagnum sp. and Typha sp. are characteristic of mires.

The assemblage from Måløv is remarkably similar to that of the Sidestrand Hall Member of the Cromer Forest-bed Formation in Britain that has also yielded Stratiotes aloides,

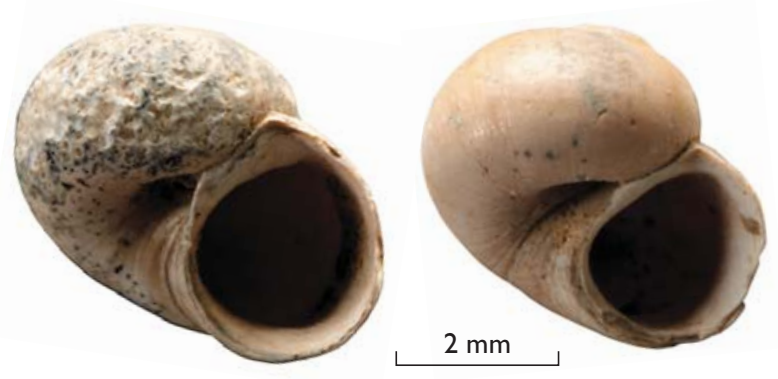

Fig. 4. Light photographs of two shells of Borysthenia naticina from Måløv.

Borysthenia naticina, Sphaerium solidum, Cyprideis torosa and Scottia (Preece et al. 2009). The depositional environment and climate must have been extremely similar but these two deposits are not necessarily of the same age.

\section{Palaeoclimate}

Several of the species recovered are warmth-demanding, especially $S$. aloides, Typha sp. and $R$. maritimus. They are widespread in Denmark today and are also found in the southern and eastern parts of Sweden. The mean July temperature at the northern range limit of Pisidium supinum is around $15^{\circ} \mathrm{C}$. B. naticina no longer lives in Denmark but has a wide modern range in central and eastern Europe, from southern and eastern Germany and Poland to Hungary, Rumania and south-western European Russia (Zilch \& Jaeckel 1962). The presence of this species indicates a more continental climate with summer temperatures higher than those in Denmark today. C. torosa is also a warmth-demanding species (Frenzel et al. 2010).

\section{Age estimate}

The assemblage recovered from Måløv clearly indicates deposition during an interglacial rather than interstadial period as was previously suggested for deposits at Måløv (Frederiksen \& Rosbirk 1999; probably the same deposit). Several of the thermophilous species present, such as Borysthenia naticina, Sphaerium cf. solidum, Stratiotes aloides, Typha sp. and Rumex maritimus, are unknown from interstadial contexts. Interstadial deposits so far described from eastern Denmark are characterised by arctic species, such as Salixpolaris, Dryas octopetala and Betula nana (Bennike et al. 1994, 2007), none of which were found at Måløv.

Fruits of Stratiotes spp. are well known from interglacial deposits in Europe, and leaf-margin spines have also been reported (Bennike \& Hoek 1999). In Denmark, fruits of $S$. aloides have been reported from the last interglacial, the Eemian and from reworked Pleistocene floras (Hartz 1909). 
Outside Denmark the species is known from the last interglacial and from several older interglacials.

Biostratigraphically, Borysthenia naticina (Fig. 4) is the most important species. This species has not previously been reported from Denmark but is known as a Pliocene fossil from southern Russia, from the Early Pleistocene of northern France and The Netherlands and from the Middle Pleistocene of central and eastern Europe. There are Middle Pleistocene records to the north-west of its modern range in the Rhine Valley. In Britain it has been reported from deposits referred to the Cromerian Complex (marine isotope stages 15 and 13), the Hoxnian (marine isotope stage 11) and to marine isotope stage 9 (Roe et al. 2009). In The Netherlands, its youngest occurrence is in a deposit referred to marine isotope stage 7 (Meijer 2003). In north-western Europe, B. naticina is thus unknown from the last interglacial stage, the Eemian, which strongly suggests that the deposit at Måløv is of preEemian age. Scottia tumida is an extinct species and so far only known from Pleistocene interglacial deposits from Germany, Poland, the United Kingdom, Hungary and Greece (Kempf 1971).

\section{Other interglacial non-marine deposits on Sjælland}

Interglacial deposits are quite common in Denmark, but most of them are found in the western and southern parts of the country where erosion by advancing glaciers and meltwater was less intense than in the eastern parts. From Sjælland, only a few interglacial deposits have been reported (Fig. 1). Most of them are marine deposits that have been referred to the Eemian or Holsteinian. Two interglacial lake deposits have been reported from Sjælland, at the Copenhagen free port and at Førslevgaard on southern Sjælland (Fig. 1). The mollusc fauna from these deposits includes the bivalve Corbicula fluminalis (Hartz 1909), which indicates an Early or Middle Pleistocene age (Meijer \& Preece 2000).

\section{Conclusions}

We conclude that the clayey deposit found at Måløv was deposited in a low-energy fluvial environment influenced by weakly brackish water. The occurrence of the gastropod $\mathrm{Bo}$ - rysthenia naticina suggests that the deposit is at least Middle Pleistocene in age. The mean July temperature was higher than in Denmark today, and the deposit is clearly interglacial rather than interstadial.

\section{References}

Bennike, O. \& Hoek, W. 1999: Late-glacial and early Holocene records of Stratiotes aloides L. from north-western Europe. Review of Palaeobotany and Palynology 107, 259-263.

Bennike, O., Houmark-Nielsen, M., Böcher, J. \& Heiberg, E.O. 1994: A multi-disciplinary macrofossil study of Middle Weichselian sediments at Kobbelgård, Møn, Denmark. Palaeogeography, Palaeoclimatology, Palaeoecology 111, 1-15.

Bennike, O., Houmark-Nielsen, M. \& Wiberg-Larsen, P. 2007: A Middle Weichselian interstadial lake deposit on Sejerø, Denmark: macrofossil studies and dating. Journal of Quaternary Science 22, 647-651.

Fredriksen, J. \& Rosbirk, E. 1999: Fundering af bro i interstadialt søbassin. Varv 1999(2), 59-63.

Frenzel, P., Keyser, D. \& Viehberg, F.A. 2010: An illustrated key and (palaeo) ecological primer for Postglacial to Recent Ostracoda (Crustacea) of the Baltic Sea. Boreas 39, 567-575.

Hartz, N. 1909: Bidrag til Danmarks tertiære og diluviale flora. Danmarks Geologiske Undersøgelse II. Række 20, 292 pp.

Kempf, E.K. 1971: Ökologie, Taxonomie und Verbreitung der nichtmarinen Ostrakoden-Gattung Scottia im Quartär von Europa. Eiszeitalter und Gegenwart 22, 43-63.

Meijer, T. 2003: The late Middle Pleistocene non-marine molluscan fauna of borehole Noorderhoeve-19E117 (province of Noord-Holland, the Netherlands). Cainozoic Research 2, 129-134.

Meijer, T. \& Preece, R.C. 2000: A review of the occurrence of Corbicula in the Pleistocene of North-West Europe. Geologie en Mijnbouw / Netherlands Journal of Geosciences 79, 241-255.

Meisch, C. 2000: Freshwater Ostracoda of western and central Europe. In: Schwoerbel, J. \& Zwick, P. (eds): Süßwasserfauna von Mitteleuropa 8(3), 522 pp. Heidelberg: Spektrum Akademischer Verlag.

Preece, R.C., Parfitt, S.A., Coope, G.R., Penkman, K.E.H., Ponel, P. \& Whittaker, J.E. 2009: Biostratigraphic and aminostratigraphic constraints on the age of the Middle Pleistocene glacial succession in north Norfolk, UK. Journal of Quaternary Science 24, 557-580.

Roe, H.M., Coope, G.R., Devoy, R.J.N., Harrison, C.J.O., Penkman, K.E.H., Preece, R.C. \& Schreve, D.C. 2009: Differentiation of MIS 9 and MIS 11 in the continental record: vegetational, faunal, aminostratigraphic and sea-level evidence from coastal sites in Essex, UK. Quaternary Science Reviews 28, 2342-2373.

Zilch, A. \& Jaeckel, S.G.A. 1962: Mollusca. Die Tierwelt Mitteleuropas 2(1), 294 pp. Leipzig: Verlag von Quelle \& Meyer.

\footnotetext{
Authors' addresses

O.B., E.L. \& H.J. G., Geological Survey of Denmark and Greenland, ØsterVoldgade 10, DK-1350 Copenhagen K, Denmark. E-mail: obe@geus.dk

R.C.P., Department of Zoology, University of Cambridge, Downing St., Cambridge CB2 3EJ, UK.

F.V., Institute of Geology and Mineralogy, University of Cologne, Zülpicher Str. 49, 50674 Cologne, Germany.
} 